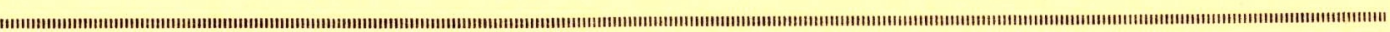

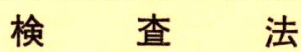

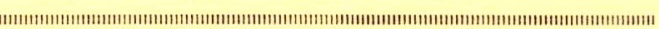

\title{
Osmotic fragility test
}

溶血性貧血の補助的診断法の一つである。原 理は, 種々の濃度の低張食塩水中に定量的に血 液を滴下し室温で一定時間粰置後, 各濃度液中 で起こった溶血の程度を光電比色計を用いて測 定する事により赤血球の浸透圧抵抗性を検べる ことである。ここでは, 最も標準的な方法とし て広く行なわれている Parpart らの方法につい て述べ, その後成績と貧血のタイプとの関係に ついて触れる。

\section{<試薬>}

$\mathrm{pH} 7.4$ の緩衝食塩水溶液を用いる。次のよ らな貯蔵液をつくっておくと便利である。 $\mathrm{NaCl}$ $90 \mathrm{~g}, \mathrm{Na}_{2} \mathrm{HPO}_{4} 13.65 \mathrm{~g}$ (または $\mathrm{Na}_{2} \mathrm{HPO}_{4} \cdot 2$ $\left.\mathrm{H}_{2} \mathrm{O} 17.115 \mathrm{~g}\right) \mathrm{NaH}_{2} \mathrm{PO}_{4} \cdot 2 \mathrm{H}_{2} \mathrm{O} 2.43 \mathrm{~g}$ を蒸溜 水にとかし $1 l$ とする。この液の浸透圧は $10 \%$ 食塩水と等しく, 密栓して保存すれば数カ月間 は安定である。以下何\%液というのは, その濃 度の食塩水と同じ浸透圧を示す緩衝食塩水液の 事である。この stock solution からつくった 1 \%液をさらに稀釈して，0.9,0.75,0.65,0. $60,0.55,0.50,0.40,0.35,0.30,0.25$, $0.20 ， 0.10 \%$ にしたものを反応に用いる。これ らの液も $4^{\circ} \mathrm{C}$ に保存すれば数週間は使用でき るのでおの打の $50 \mathrm{~m} l$ ずつ作って拈くと便利 だが,カビが生えたものは捨てる。

\section{<検查方法 >}

サンプルにはヘパリン血または脱線維素血を 使用する。苳酸塩やクエン酸塩を抗凝固剂とし
て用いると反応液の浸透圧に影響を与えるので 好ましくない。新鮮血による検查は採血後 2 時 間以内に, $4^{\circ} \mathrm{C}$ に血液を保存した場合でも 6 時 間以内に行なうべきである。検査は，上記の濃 度系列の液 $5 \mathrm{ml}$ 中に血液 $0.05 \mathrm{ml}$ を加兄てよ く混和し30分間室温に放置後再び良く混ぜてか ら $1,200 \sim 1,500 \mathrm{~g}$ で 5 分間遠沈して上清をと り, 光電比色計を用いて $540 \mathrm{~m} \mu$ での吸光度を 測定する。 $0.1 \%$ 液の上清を $100 \%$ 溶血， $0.9 \%$ 上清（もしこれが溶血を起こしていれば $1.2 \%$ 上清）を盲検（ $0 \%$ 溶血）とし，各系の溶血の 度合をパーセントであらわす。100\%溶血液の 吸光度が 0.5 位になるように溶血系なたはセル の厚みをセットするのが望ましい。必要に応じ て溶血液を $0.1 \%$ 液で 2 倍に稀釈してから吸光 度を測定するか, 最初から反応液 : 血液 $=200$ ：1にしておく。結果の記録法にはいろいろあ るが, 溶血開始最大濃度, $50 \%$ 溶血濃度, 100 \%溶血最大濃度を記録しておくと良い。また横 軸に液の濃度をとり, 縦軸に溶血の度合をとっ てグラフを書くのが一般的でみやすい。正常の カーブを図に示したが, 対称的な $\mathrm{S}$ 字状のカー ブを呈する。検査に影響を与える因子として, 液量と血液量の相対比, 血液滴下後の反応液の $\mathrm{pH}$, 温度がある。液量比はそのまま比色でき る点扣よび添加血漿による浸透圧の影響を少な くするといら点から 100 200: 1 が良い。 $\mathrm{pH}$ 低下は脆弱性の増大を招くので, 本法ではリン 酸緩衝液を用いているが, 用いる血液の酸素飽 和度も多少の影響を与劣るため, 非常に㺖密な 


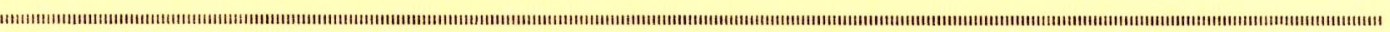

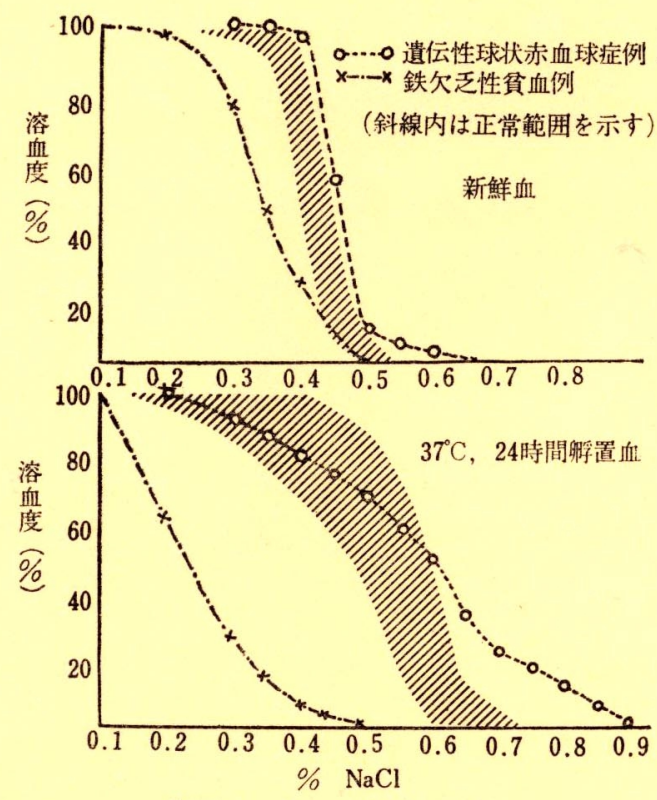

Parpart 法による溶血曲線

データが必要な時には, 血液が鮮紅色を呈する までよく混ぜて执く事が望ましい。検査温度 は, 普通は室温で差支えない。温度の低下も脆 弱性の增加をもたらし, 温度 $5^{\circ} \mathrm{C}$ なは $\mathrm{pH}$ 0.1 の変化は反応液濃度 $0.01 \%$ の変化と同じ影 響を及ぼす。以上述べた新鮮血を用いる方法の 外, 採血後 $37^{\circ} \mathrm{C}$ に24時間捊置した血液を用い て行なう方法もあるが，血液を無菌的に24時間 捊置する以外は全く同じ操作で良い。この場合 には脆弱性が立進するので $1.2 \%, 0.8 \%, 0.7$
\%の濃度の液をつくっておく。新鮮血での検査 ではわずかな異常しか示さなくても, この方法 で行なうと著明な脆弱性の增大を示す例がある ので鑑別に役立つ。

この検査に及ぼす血球側の因子としては，体 積の表面積の比, 血球膜の機能状態があげられ る。従って血球が球形に近いほどまた老化した ものほど脆弱性は元進する事になる。遺伝性球 型赤血球症 (H.S.) ではほとんど全例に脆弱性 の増加がみられ, 特に24時間孵置血球を用いた 時に著しい。このように H.S. の診断には欠く 事のできない検査法の一つである。しかし自己 免疫性溶血性貧血等他の溶血性疾患でも同様の 所見を与えるものがあるので，この検査だけで 診断を下す事はでさない。ピルビン酸キナーゼ 欠乏症でも24時間卯置血球の脆弱性は著しく増 大する。逆に脆弱性の低下をきたす例として, 鎌型赤血球性貧血, 地中海貧血, 鉄欠乏性貧血 などがある(図参照)。

ここでは触れないが, 溶血性貧血の補助診断 法には, この他 Autohemolysis test, Mechanical fragility test などがあり，これらの結果を 参考にすればさらに有力な診断の手がかりとな る。どの検査法でも同じであるが，それ一つで 診断をつけようとするのではなく, 他の検査デ 一タや臨床的所見を考光合せて診断するという 態度が大切である。 